\title{
Relationships and Community Risk Factors for Elder Abuse and Neglect: Findings from the First National Prevalence Study on Elder Maltreatment
}

\author{
Dimitrinka Jordanova Peshevska ${ }^{1 *}$, Marijana Markovik $^{2}$, Dinesh Sethi $^{3}$, Eleonora Serafimovska ${ }^{2}$ \\ ${ }^{1}$ World Health Organization, Country Office Skopje, Republic of Macedonia; ${ }^{2}$ Institute for Sociological, Political and Juridical \\ Research, Ss Cyril and Methodius University of Skopje, Republic of Macedonia; ${ }^{3}$ World Health Organization, Regional Office \\ for Europe, Copenhagen, Denmark
}

\begin{abstract}
Citation: Jordanova Peshevska D, Markovik M Sethi D, Serafimovska E. Relationships and Community Risk Factors for Elder Abuse and Neglect: Findings from the First Nationa Prevalence Study on Elder Maltreatment. OA Maced J Med Sci. 2014 Jun 15; 2(2):367-372. http://dx.doi.org/10.3889/oamjms.2014.063

Key words: prevalence; elder abuse and neglect; community and relationship risk factors: female respondents; Republic of Macedonia.

"Correspondence: Dimitrinka Jordanova Peshevska, MS. World Health Organization, Country Office Skopje, "Drezdenska 22", 1000 Skopje, Republic of Macedonia. Tel: +389 3063 710; Fax: +389 23063 710. E-mail: jpd@euro.who.int

Received: 25-Feb-2014; Revised: 03-Mar2014: Accepted: 30-Mar-2014; Online first: 11-May-2014

Copyright: () 2014 Jordanova Peshevska et al. This is an open access article distributed under the terms of the Creative Commons Attribution License, which permits unrestricted use, distribution, and reproduction in any medium, provided the original author and source are credited.

Competing Interests: The authors have declared that no competing interests exist.
\end{abstract}

\begin{abstract}
OBJECTIVES: The objective of the study was to mesaure the 12-months prevalence of elder abuse and neglect in private huousehold and to examine the relationship and community level risk factors for elder abuse and neglect.

METHOD: Total of 960 respondents aged 65 years and above in private households, from all eight statistical regions participated in the study. Nationally stratified quota sampling procedure was applied, through four stages. Information was collected in face-to face interview on sociodemographic, healthy life style, physical and mental health, and abuse and neglect types characteristics of elder population. Data were examined using descriptive statistics, binary logistic regression, and odd ratios (OR). Statistical significance was set up at $\mathrm{p}<0.05$.

RESULTS: The respondents reported prevalence of psychological abuse $25.7 \%$, followed by financial abuse $12 \%$, neglect $6.6 \%$, physical abuse $5.7 \%$, physical injury $3.1 \%$, and sexual abuse $1.3 \%$ (reported only in female respondents) in the previous 12-months. Living with close relatives, dissatisfaction with the household income, less equipped households, lacking property of house/flat are associated risk factors for elder maltreatment on relationship level. Living in the northeast, southeast, and Polog region are associated risk for elder maltreatment.
\end{abstract}

CONCLUSION: Study findings emphasised the previous data obtained with regards to the community and relationships risk factors for elder maltreatment.

\section{Introduction}

Maltreatment of older people, termed 'elder abuse', was first described in British scientific journals in 1975 [1]. In 1996, the Forty-Ninth World Health Assembly (WHA) adopted WHA Resolution 49.25 [2], declared violence a major and growing public health problem across the world. Later, in the 1980s in some countries, scientific research and government action emerged. World health report on violence and health in 2002 [3] and WHA Resolution 56.24 [4], put violence on the international agenda as a leading worldwide public health problem. The major political influence was followed by increasing body of research on elder abuse and neglect [5], focusing on risk factors associated with elder maltreatment.
The Political Declaration and Madrid International Plan of Action on Ageing (MIPAA) in 2002 pointed out that one of the most common forms of elderly abuse is neglect or failure to fulfil a caregiving responsibility [6]. Elder maltreatment has received another political attention with the Toronto Declaration on the global Prevention of Elder Abuse [7]. The Ministerial Conference in 2007, León adopted the Ministerial Declaration "A Society for All Ages: Challenges and Opportunities" [8] in order to emphasize inclusion of elderly in all aspects of the society.

Life expectancy in developed countries is increasing, as a result of improved medical technology and improved quality of life in general. The world's 
elderly population - people 60 years of age and older - is 650 million. By 2050, this older population is forecast to reach 2 billion $[9,10]$.

In the country a systematic scientific approach to elder maltreatment has been lacking until recently. Gaining its independence, the country has gone through a period of transition which has had a major impact on the health and social care system and contributed to the loss of social networks. Increased unemployment, reaching almost $31 \%$ in 2010 , has affected the structure of the working population [11]. Older people with pensions are very often the only source of income in the family, making the younger generation dependent on them. At the same time, older persons being sometimes physically and psychologically dependent on other family members are susceptible to abuse and neglect. National report on violence and health has highlighted elder abuse as a public health concern [12]. However, the only data on elder maltreatment are based on reports of maltreatment to agencies working in the area of domestic violence [13].

In this study the terms 'elderly' or 'older people' are used and refer to people aged 65 years and above [9, 14]. According to the definition for elderly people given by $\mathrm{WHO}$, the critical age for classification as old is 65 years [3, 15]. This definition is not universal, however. Most developed countries accept the chronological age of 65 years and over as a definition of elderly, but in some parts of the developing world, for example, this is not the case [15].

Different researchers, policy-makers and others use diverse definitions of elder maltreatment, arising from different perspectives and research questions. The conceptual framework definition used in this study is the one adopted by WHO and INPEA where elder abuse is defined as a single or repeated act, or lack of appropriate action, occurring within any relationship where there is an expectation of trust, which causes harm or distress to an older person [3, 16]. According to $\mathrm{WHO}$, elder abuse can take the various forms of physical, psychological, emotional, sexual and financial abuse. It can also result from intentional or unintentional neglect $[9,17]$.

The WHO public health approach in the ecological model of violence gives a framework for understanding violence in general, including abuse or neglect of older people. The ecological model of violence has its roots in Bronfenbrenner's ecological paradigm which was first introduced in 1970 [18, 19]. The ecological framework employs a multidimensional view of interpersonal violence at older persons. It examines violence as an outcome of the interaction between different levels of individual, relational, community and societal factors.

This paper has focused on: 1) risk factors on the relationship level: household size, household composition (cohabiting with partner, children, grandchildren. etc), and household income; 2) risk factor on the community level was the Region where elderly people live.

The data used in this article is an integral part of the data collected for more comprehensive project "A Community survey in Macedonia of the prevalence of elderly abuse". The study has been conducted during the period from December 2011 to February 2012. Implementation of the study was enabled with technical and financial support by the World Health Organization in collaboration with the Institute of Sociological, Political and Juridical Research in Skopje.

\section{Method}

The study is a community based household survey at national level, involved administering a faceto-face questionnaire. Total of 960 respondents aged 65 years and above in private households, from all eight statistical regions participated in the study, which represents $0.4 \%$ of the total number of people 65 years of age and above. Sampling was carried out by quota stratified sampling. The first step was selection of potential participants by strata, based on criteria of gender, ethnicity, residence (city/village), and municipality (percentage of respondents from each municipality correspond to its contribution to the total population). The quota of respondents in each strata depended on population distribution [20].

\section{Measures}

The questionnaire used in the Macedonian survey mostly follow the methodology of the: ABUEL survey -Abuse of Elderly in Europe, a multinational prevalence survey, conducted in Germany, Greece, Italy, Lithuania, Portugal, Spain, Sweden [21], and AVOW- Prevalence study of abuse and violence against older women, a multicultural survey conducted in Austria, Belgium, Finland, Lithuania and Portugal [22].The questionnaire enclosed questions on: sociodemographic data; healthy life styles data (smoking, alcohol use, diet); physical and mental health, and exposure to abuse/neglect (psychological abuse, physical abuse, physical injury; financial abuse; sexual abuse and neglect). Statistical significance was set up at $p<0.05$. The final version of the questionnaire was available both in Macedonian and Albanian language. A qualitative analysis of the Final Questionnaire Form has been undertaken by a Focus group of experts and the Scientific Committee of the study. The ethics committee (professors from the Law and Medical Faculty of the University "St. Kiril and Metodij") granted ethical approval to the study. The inclusion criterion for involvement to participation in the study was absence of mental impairment (such as dementia). Potential respondents were screened 
using questions from the Mini-Mental State Examination (MMSE) [23].

\section{Data analysis}

Data input and data analysis were conducted in the SPSS (Statistical Package for Social Sciences, Version 19.0), used to analyze the data gathered in the survey. The following statistical methods have been used: Factor analysis, Chi-square analysis, statistically significant difference between the percentage and binary logistic regression. Statistical significance was set at $p<0.05$ for all analyses.

Table 1: Characteristics of the sample $(\mathrm{N}=960)$.

\begin{tabular}{|c|c|}
\hline Gender & Total\% \\
\hline Male & 44.7 \\
\hline Female & 55.3 \\
\hline Age & Total \% \\
\hline $65-69$ & 32.0 \\
\hline $70-74$ & 28.9 \\
\hline $75-79$ & 22.1 \\
\hline $80-84$ & 12.7 \\
\hline Over 85 & 4.3 \\
\hline Ethnicity & Total \% \\
\hline Macedonian & 76.4 \\
\hline Albanian & 16.0 \\
\hline Roma & 1.9 \\
\hline Serb & 1.1 \\
\hline Vlach & 0.5 \\
\hline Turkish & 2.1 \\
\hline Bosnian & 1.0 \\
\hline Other & 1.0 \\
\hline Level of education & Total \% \\
\hline No education & 10.4 \\
\hline Did not complete primary school & 25.8 \\
\hline Primary school education & 26.8 \\
\hline Secondary education & 25.2 \\
\hline University/other higher education & 11.2 \\
\hline Specialist, MA, PhD & 0.6 \\
\hline Marital status & Total \% \\
\hline Single (never married) & 3.6 \\
\hline Married/civil partnership) & 56.7 \\
\hline Divorced & 2.0 \\
\hline Widowed & 37.7 \\
\hline Occupational status & Total \% \\
\hline Fully retired & 87.5 \\
\hline Full-time employed & 0.6 \\
\hline Part-time employed & 0.4 \\
\hline Unemployed & 11.5 \\
\hline Personal income in euro & Total \% \\
\hline Up to 80 & 7.4 \\
\hline $81-146$ & 40.8 \\
\hline $147-226$ & 27.5 \\
\hline $227-307$ & 10.8 \\
\hline $308-388$ & 3.4 \\
\hline $389-467$ & 1.3 \\
\hline$<468$ & 0.9 \\
\hline No income & 7.9 \\
\hline Region & Total\% \\
\hline Pelagonija & 13.5 \\
\hline Vardar & 8.0 \\
\hline North-eastern & 7.4 \\
\hline South-western & 9.8 \\
\hline Skopje & 30.2 \\
\hline South-eastern & 9.1 \\
\hline Polog & 10.8 \\
\hline Eastern & 11.2 \\
\hline
\end{tabular}

Binary logistic regression was conducted in order to compare the probability "have been abused/neglected" dependent on the level or category of the risk factors on relationship and community level. The binary logistic regression for the selected variables shows several significant results.

\section{Results}

Regarding socio-demographic characteristics of the sample, men (44.7\%) and women (55.3\%) are almost identical to the planned percentages as per population age distribution. The vast majority of the respondents are in the age group 65-69 years $(32.1 \%)$, while the least group was aged over 85 years (4.3\%). Regarding distribution of the respondents by ethnicity, Macedonians are $76.4 \%$, followed by Albanians (16.0\%) and other groups as per country population distribution (see Table 1). The country has eight statistical regions and the respondents are distributed with regards to the regions as per country population distribution. The highest percentage of respondents had only completed primary school (26.8\%), and the lowest percentage of respondents held higher degrees $(0.6 \%)$ as presented in Table 1 . The highest percentages of the respondents are in the groups of married/cohabitation (56.7\%) and widow (37.7\%). Older people living alone represent up to $15.8 \%$ of the sample, while the highest percentage of respondents are living in households with more than four family members is $39.3 \%$. The percentage of respondents living with a partner $56.7 \%$ is little bit higher than that for participants without a partner $43.3 \%$ (Table 1). The highest percentage of participants had an average number of facilities (63.7\%). The highest percentage of participants answered that total household income partially satisfied their needs $(49.6 \%)$.

Overall prevalence rates of elder abuse and neglect of $32.0 \%(\mathrm{~N}=307)$ have been reported by respondents in the study (see Table 2). Regarding various types of abuse and neglect, psychological abuse was the most frequent $(25.7 \%)$, followed by financial abuse (12.0\%), physical abuse (5.7\%), physical injury (3.1\%) and sexual abuse only in women (1.3\%).

Table 2: Overall prevalence rates of abused/neglected of older persons.

\begin{tabular}{lccc}
\hline $\begin{array}{l}\text { Prevalence of } \\
\text { abused/neglected }\end{array}$ & Total \% & Male \% & Female\% \\
\hline Not abused/neglected & 68 & 32.1 & 35.9 \\
Abused/neglected & 32 & 12.6 & 19.4 \\
Total & 100 & 44.7 & 55.3 \\
\hline
\end{tabular}

\section{Relationship level risk factors}

Risk factors at the level of relationship that have been explored were: cohabiting with partner, children, grandchildren, satisfaction with household income, and owning house/flat as presented in Table 3.

Few risk factors were recognized as relevant risk factors for elderly abuse on relationships level. Cohabitant status (those living with closer relatives) had a higher likelihood of being abused/neglected compared to those living with a partner, a partner and child, with a child only and wider family, or living alone. Total household income satisfaction was found 
a relevant risk factor. Respondents who were entirely dissatisfied had a higher likelihood of being abused rather than those who were "completely satisfied" or "partially satisfied".

Table 3. Likelihood of elder abuse/neglect on relationship level risk factors.

\begin{tabular}{|c|c|c|}
\hline \multirow[b]{2}{*}{ Relationship level } & & $\begin{array}{l}\text { Abused/neglected versus not } \\
\text { abused/not neglected }\end{array}$ \\
\hline & & Odds ratio \\
\hline \multirow{6}{*}{$\begin{array}{l}\text { Cohabitant } \\
\text { status }\end{array}$} & Alone & Ns \\
\hline & Partner & Ns \\
\hline & Partner/child & Ns \\
\hline & Child & Ns \\
\hline & Close relative & $1.773^{\star \star}$ \\
\hline & Wider & Ns \\
\hline \multirow{3}{*}{$\begin{array}{l}\text { Satisfaction with } \\
\text { household } \\
\text { income }\end{array}$} & Completely satisfied & Ns \\
\hline & Partially satisfied & Ns \\
\hline & Completely dissatisfied & $1.331^{*}$ \\
\hline \multirow{3}{*}{$\begin{array}{l}\text { Household } \\
\text { facilities }\end{array}$} & Fully equipped & Ns \\
\hline & Partly equipped & Ns \\
\hline & Less equipped & $3.066^{\star \star}$ \\
\hline Ownership & Property (house/flat) & $2.978^{\star \star}$ \\
\hline
\end{tabular}

Household equipment was also indicated as a risk factor for elder maltreatment. Respondents who reported that their households are less equipped (equipped means having: own room, heating, cooling, lightening, toilet and shower) had a higher likelihood of being abused. In binary logistic regression analysis living with close relatives $(\mathrm{OR}=1.77)$, dissatisfaction with the household income $(O R=1.3)$, less equipped households $(O R=3.07)$, lacking property of house/flat $(\mathrm{OR}=2.98)$, are associated risk factors for elder maltreatment on relationship level (see Table 3).

Living with partner has been identified as a risk factor for all types of abuse except for neglect. In the binary logistic regression living with partner was associated with psychological abuse $(\mathrm{OR}=1.02)$, with physical abuse $(\mathrm{OR}=3.01)$, with physical injuries (OR $=4.45)$, with financial abuse $(O R=1.58)$, and sexual abuse for women only $(\mathrm{OR}=7.35)$ as presented in Table 4.

Table 4: Living with/without partner as a risk factor for elder abuse.

\begin{tabular}{lllllll}
\hline \multicolumn{5}{c}{ Odds ratio } \\
\hline Partnership & $\begin{array}{l}\text { Psychological } \\
\text { abuse }\end{array}$ & $\begin{array}{l}\text { Physical } \\
\text { abuse }\end{array}$ & $\begin{array}{l}\text { Physical } \\
\text { injuries }\end{array}$ & $\begin{array}{l}\text { Financial } \\
\text { abuse }\end{array}$ & $\begin{array}{l}\text { Sexual } \\
\text { abuse }\end{array}$ & Neglect \\
\hline $\begin{array}{l}\text { With/without } \\
\text { partner }\end{array}$ & $1.025^{*}$ & $3.407^{* *}$ & $4.481^{* *}$ & $1.589^{*}$ & $7.347^{* *}$ & Ns \\
\hline Binary Logistic Regression coefficient ${ }^{*} \mathrm{p}<0.05^{* *} \mathrm{p}<0.01$. & &
\end{tabular}

Respondents who do not have an own house or flat had a higher likelihood of being abused/neglected than those owning a house or flat (see Table 5). In the binary logistic regression not owning house/flat has been associated with: physical injuries (OR $=3.29$ ), sexual abuse in women only (OR $=8.95)$ and neglect $(\mathrm{OR}=2.70)$.

\section{Community level risk factors}

Only one risk factor at the third level, community, was explored - the region where the older people live. Region is considered to be a relevant risk factor in the study. Higher levels of abuse and neglect were observed in the north-east, south-east, and the
Table 5: Ownership of house/flat a risk factor for elder abuse.

\begin{tabular}{lllll}
\hline \multicolumn{5}{c}{ Odds ratio } \\
\hline Ownership & Abuse & $\begin{array}{l}\text { Physical } \\
\text { injuries }\end{array}$ & Sexual abuse & Neglect \\
\hline Property & $2,978^{* *}$ & $3.287^{* *}$ & $8.948^{* *}$ & $2.706^{* *}$ \\
\hline Binary Logistic Regression coefficient ${ }^{*} \mathrm{p}<0.05^{* *} \mathrm{p}<0.01$.
\end{tabular}

Polog Regions of the country. The lowest level of abuse and neglect was reported in the Region of Skopje. In binary logistic regression living in the northeast $(O R=1.77)$, southeast $(O R=2.25)$, and Polog region $(\mathrm{OR}=1.69)$ are associated with risk for elder maltreatment (Table 6).

Table 6: Likelihood of alder abuse/neglect and society level risk factor.

\begin{tabular}{llc}
\hline \multicolumn{2}{l|}{ Community/society level } & $\begin{array}{c}\text { Abused/neglected versus not } \\
\text { abused/not neglected } \\
\text { Odds ratio }\end{array}$ \\
\hline \multirow{4}{*}{ Region } & Pelagonija & $\mathrm{Ns}$ \\
& Vardar & $\mathrm{Ns}$ \\
& Northeast & $1.765^{*}$ \\
& Southwest & $\mathrm{Ns}$ \\
& Skopje & $\mathrm{Ns}$ \\
& Southeast & $2.251^{* *}$ \\
Binary Logistic Regression coefficient ${ }^{*} \mathrm{p}<0.05$ and ${ }^{* *} p<0.01$. & $1.681^{*}$ \\
& Polog & $\mathrm{Ns}$ \\
\hline
\end{tabular}

\section{Discussion}

Although large body of the research have examined the risk factors for elderly abuse in the past year, most of the information is based on studies from the United States and the United Kingdom (and recently in other countries in the European Union). Among the risk factors identified are quality of the relationship between the caregiver and the recipient of care, cognitive dysfunctions or impairment in the abused, particularly in the oldest ones, and social isolation of older people [9, 17, 24].

Data from a study in New Zealand have examined risk and protective factors. Among the risk factors noted were isolation, household living arrangements, and ongoing partner abuse [25]. Correspondingly our study living with a partner as identified risk factors for elder maltreatment compared to those who live without a partner (except in the case of neglect).

A study from Ireland [26] found that household income is relevant risk factor for older people being abused. Similarly as in the Macedonian study respondents who say that the total family income cannot completely satisfy their needs increase 1.4 times more the likelihood of older persons to experience abuse.

Important factor increasing the risk of abuse is shared long-term living arrangements between the perpetrator and victim. When caregiver and care receiver live in the same household, there are not many possibilities to keep a distance from each other [27, 28, 29]. Correspondingly in our study, statistical significance (binary logistic regression $p<0.05$ ) of reported abuse was found between respondents who 
live with another person. Older people living with a partner were at greater likelihood of being abused compared with those living without a partner, for every type of abuse. Those living with a partner were three times more likely to be physically abused, four times more likely to be physically injured, one time more likely to be psychologically abused, and seven times more likely to be sexually abused (for women only).

The most common risk factors highlighted in exploration of the phenomenon of elderly abuse identified in other, but as well in our study, were living arrangements, mental health status, and social support [27, 28, 29]. Interacting on an almost daily basis, sharing living accommodation with a perpetrator and living in rented accommodation as opposed to home ownership may increase the opportunity for violent encounters [9, 25]. Various studies show that living alone reduces the risk of maltreatment, whereas living with a family member is a risk factor for elderly abuse and neglect [9]. Our study showed that those living with closer relatives increase for 1.8 times more the likelihood of being abused/neglected compared to those living with a partner, partner and child, with a child only and wider family, or live alone.

In the Macedonian study those who are dissatisfied with household income; their homes lack equipment to the satisfactory level (toilet, own room, lightening, cooling, heating, etc.) and do not own a house or flat had greater estimated probability for being maltreated than those who are satisfied with household income or had an adequately equipped own house or flat.

Region has been identified as relevant risk factor at community level. Respondents who live in north-east region are 1.8 times more likely exposed to abuse. Living in the south-east region are 2.3 times more increasing the likelihood of maltreatment and living in the Polog region had a 1.7 higher estimated probability of being maltreated compared to those living in other regions. Identified regions are those with high poverty rate [20] and support the fact that economics and societal factors are likely to play a role in creating a climate in which elderly maltreatment is prevalent $[9,30]$.

The study limitations are related manly related to not covering the most vulnerable groups (older people suffering from a severe dementia and elderly who live in care homes or are hospitalized or imprisoned). The study did not involve societal factors which might be relevant for elderly maltreatment (negative attitudes and stereotypes towards older people or cultural norms supportive of violence).

As the main findings show that elderly maltreatment is an outcome of the interaction between various factors, and we should take into consideration all risk factors in an overall country picture in order to tackle elder maltreatment prevention. Identifying different risk factor can be leading for the creative and constructive efforts in the process of prevention and management of the problems and issues relating to the elderly. Our country can follow other countries examples that have in place evidence based practices for prevention, detection, and intervention for abuse of older adults [3, 9]. Strengthening elder abuse and neglect prevention should be facilitated with enlargement of the role of health, social and other sectors in primary prevention, promotion of evidencebased practices (incorporating prevention in home visiting programmes, and implementation of family support programmes); capacity-building (education and training for professionals in government and NGOs for prevention of elder abuse and neglect at all levels, with particular focus on primary prevention); and public awareness campaigns to change cultural norms $[3,9]$. The study findings should promote national policy dialogue for development of national policies and programmes targeting elderly population.

\section{References}

1. Burston RG. Granny-battering. BMJ. 1975:592.

2. World Health Organization. Forty-ninth World Health Assembly Resolution, WHA49.25 Prevention of violence: a public health priority. Geneva: WHO, 1996.

3. Krug EG, Dahlberg LL, Mercy JA, Zwi AB \& Lozano R, eds. World report on violence and health. Geneva: World Health Organization, 2002.

4. Butchart A, Phinney A, Check P, Villaveces A, eds. Preventing violence: a guide to implementing the recommendations of the World report on violence and health. Geneva: Department of Injuries and Violence Prevention, World Health Organization, 2004.

5. Amstadter AB, Begle AM, Cisler JM, et al. Prevalence and correlates of poor self-rated health in the United States: the National Elder Mistreatment Study. Am J Geriatr Psychiatry. 2010; 18(7):615-623.

6. United Nations. Report of the Second World Assembly on Ageing. Madrid, 2002.

7. The Toronto Declaration on the Global Prevention of Elder Abuse. Geneva: WHO, 2002. http://www.who.int/ageing/projects/elder_abuse/alc_toronto_de claration_en.pdf?ua=1. Accessed February 7, 2014.

8. Economic Commission for Europe. Report of the UNECE Ministerial Conference on Ageing. Leon, 2007. (http://www.unece.org/fileadmin/DAM/pau/_docs/ece/2007/EC E_AC30_2007_2.e.pdf. Accessed November 29, 2012).

9. Sethi D, Wood S, Mitis F, et al., eds. European report on preventing elder maltreatment. Copenhagen: WHO Regional Office for Europe, 2011.

10. World Health Organization. Social development and ageing. Crisis or opportunity? Special panel at Geneva 2000. Geneva: WHO, 2000.

11. State Statistical Office. Macedonia in figures. Skopje: State Statistical Office of the Republic of Macedonia, 2010.

12. Ministry of Health. Report on violence and health in Macedonia and guide for prevention. Skopje, Ministry of Health of the Republic of Macedonia, 2006.

13. Ministry of Labour and Social Policy. Annual report 2010. Skopje: Ministry of Labour and Social Policy of the Republic of Macedonia, 2010. 
14. Connel CM. Older adults in health educational research: same recommendations. Health Educational Research. 1999; 14 (3): 427-431.

15. WHO. Definition of older or elderly person http://www.who.int/healthinfo/survey/ageingdefnolder/en/. Assessed February 7, 2014.

16. WHO/INPEA. Missing voices. Geneva:World Health Organisation, 2002. (http://whqlibdoc.who.int/hq/2002/WHO_NMH_VIP_02.1.pdf.

Accessed December 12, 2011)

17. National Committee for the prevention of elder abuse/MetLife Mature Market Institute. The essentials: Preventing elderly abuse. New York: NY, 2011.

18. Bronfenbrenner $U$. The ecology of human development: Experiments by nature and design. Cambridge, MA: Harvard University Press, 1979.

19. Bronfenbrenner U. Ecological model of human development. International Encyclopaedia of Education. $2^{\text {nd }}$ ed.1993; (3).

20. State Statistical Office. Estimation of population on 30.06.2010 and 31.12.2010 according to the gender by municipality and statistical regions. Skopje: State Statistical Office, Republic of Macedonia, 2011. http://www.stat.gov.mk/publikacii/2.4.11.14.pdf. Accessed November 20, 2011.

21. Karolinska Institute. ABUEL, Abuse of elderly in Europe Stockholm: Karolinska Institute, 2009. abuel.org/project.html. Accessed October 9, 2011.

22. National Institute for Health and Welfare THL. Prevalence study of violence and abuse against older women (AVOW). Helsinki: National Institute for Health and Welfare THL, 2010. http://www.thl.fi/avow. Accessed October 9, 2011.

23. Krsteska R. Mini Mental Test kaj Alchajmerova i vaskularna demencija. [Mini Mental Test in Alzheimer's and vascular dementia.]. Makedonski Medicinski Pregled [Macedonian Medical Review]. Skopje: University "Ss Cyril and Methodius", 2007.

24. Centers for Diseases Control and Prevention. Understanding elder abuse. 2013. http://www.cdc.gov/violenceprevention/pdf/em-factsheet-a.pdf. Accessed February 7, 2014.

25. Peri K, Fanslow J, Hand J, Parson J. Elder abuse and neglect: exploration of risk and protective factors. Wellington: Families Commission. 2004. http://www.abuel.org/docs/04elder.pdf Accessed February 13, 2012.

26. Naughton C, Drennan J, Treacy MP, et al., eds. Abuse and Neglect of Older People in Ireland: Report on the National Study of Elder Abuse and Neglect. Dublin: University College Dublin, 2010.

27. Price T, King PS, Dillard RL, Bulot JJ. Elder Financia Exploitation: Implications for Future Policy and Research in Elder Mistreatment. West JEM. 2011; 12 (3):354-356.

28. Wilbur KH, Reynolds SL. Introducing a Framework for Defining Financial Abuse of the Elderly, Journal of Elder Abuse \& Neglect. 1997; 8(2): 61-80.

29. Namkee GC, Mayer J, Elder abuse, neglect and exploitation: risk factors and prevention strategies, Journal of Gerontological Social Work. 2000; 33(2).

30. National Research Council. Elder Mistreatment: Abuse, Neglect, and Exploitation in an Aging America. Washington, DC: The National Academies Press, 2003. 